\title{
Pengaruh Kepemilikan Manajerial, Employee Diff dan Risiko Litigasi terhadap Manajemen Laba pada Perusahaan Manufaktur di Indonesia
}

\author{
Pasek Wayan Gejen Tatar ${ }^{1 *}$, Edy Sujana ${ }^{2}$ \\ ${ }^{123}$ Program Studi Akuntansi S1, Universitas Pendidikan Ganesha, Singaraja, Indonesia \\ *ppasek16@gmail.com ${ }^{18}$
}

\begin{abstract}
Abstrak
Penelitian ini bertujuan untuk menguji pengaruh kepemilikan manajerial, employee diff dan risiko litigasi terhadap manajemen laba pada perusahaan manufaktur yang terdaftar di Bursa Efek Indonesia tahun 2016-2018. Penelitian ini menggunakan metode kuantitatif. Teknik pengambilan sampel dalam penelitian ini menggunakan purposive sampling dengan menyesuaikan dengan kriteria yang telah ditetapkan sehingga memperoleh 99 sampel. Data pendukung yang digunakan didapat dari situs resmi Bursa Efek Indonesia (BEI) dengan periode 3 tahun. Dalam menganalisis data penelitian, digunakan uji regresi linier berganda dengan bantuan program IBM SPSS versi 20. Hasil penelitian ini menyatakan bahwa kepemilikan manajerial, employee diff dan risiko litigasi secara parsial berpengaruh positif dan signifikan terhadap manajemen laba. Dalam hal ini semakin meningkat kepemilikan manajerial, employee diff dan risiko litigasi maka manajemen laba juga akan semakin meningkat.
\end{abstract}

Kata Kunci: Kepemilikan Manajerial, Employee Diff, Risiko Litigasi, Manajemen Laba

\section{Abstract}

This study aims to examine the effect of managerial ownership, employee diff and litigation risk on earnings management in manufacturing companies listed on the Indonesia Stock Exchange 2016-2018. This research uses quantitative methods. The sampling technique in this study used purposive sampling by adjusting the predetermined criteria so as to obtain 99 samples. The supporting data used is obtained from the official website of the Indonesia Stock Exchange (BEI) with a period of 3 years. In analyzing research data, multiple linear regression tests were used with the help of the IBM SPSS version 20 program. The results of this study indicate that managerial ownership, employee diff and litigation risk partially have a positive and significant effect on earnings management. In this case the increasing managerial ownership, employee diff and litigation risk, the earnings management will also increase.

Keywords: Managerial Ownership, Employee Diff, Litigation Risk, Earnings Management

\section{Pendahuluan}

Perekonomian suatu Negara, dapat ditunjang dengan adanya perusahaan-perusahaan yang berkembang. Perusahaan manufaktur adalah salah satu sektor yang dapat menunjang perekonomian di suatu Negara. Peranan perusahaan manufaktur dalam menunjang perekonomian suatu Negara terlihat dari produk-produk yang dihasilkannya banyak digunakan untuk memenuhi kebutuhan sehari-hari masyarakat. Maka dari itu perusahaan manufaktur haruslah dikelola dengan baik agar dapat meningkatkan kinerja perusahaan. Dalam suatu perusahaan perlukan adanya laporan keuangan untuk menjadi tolak ukur investor dalam berinvestasi.

$\begin{array}{ll}\text { History: } & \text { Publisher: Undiksha Press } \\ \text { Received: } & \text { Licensed: This work is licensed under } \\ \text { Revised: 26 Juni } 2021 & \text { a Creative Commons Attribution 3.0 License } \\ \text { Accepted: 28 Juni } 2021 & \text { CC OP } \\ \text { Published: 30 Juni } 2021 & \end{array}$


Laporan keuangan adalah media yang paling penting untuk menilai kondisi ekonomi dan prestasi manajemen. Salah satu laporan keuangan yang sering digunakan sebagai pengambilan keputusan adalah laba. Menurut Priswita \& Taqwa (2019), informasi laba merupakan indikator untuk mengukur kinerja atas pertanggungjawaban manajemen dalam mencapai tujuan operasi yang telah ditetapkan serta membantu pemilik untuk memperkirakan earnings power perusahaan dimasa yang akan datang. Evaluasi jumlah laba yang dihasilkan oleh perusahaan dapat menjadi perkiraan seberapa besar return yang akan diperoleh saat berinvestasi dalam perusahaan. Manajemen perusahaan memiliki tujuan positif dan negatif saat menyusun laporan keuangan. Dari sudut pandang positif maupun negatif ini tergantung dari pandangan masing-masing pihak yang berkepentingan seperti pihak manajer atau pemegang saham. Manajer perusahaan dapat melakukan berbagai cara atau usaha untuk menaikkan laba agar perusahaan dinilai baik oleh pihak yang berkepentingan. Manajer tidak menanggung resiko atas kesalahan dalam pengambilan keputusan, resiko tersebut ditanggung oleh pemegang saham. Hal ini menimbulkan konflik kepentingan antara manajer dan pemegang saham. Konflik kepentingan ini akan berdampak pada penyusunan laporan keuangan perusahaan.

Salah satu kasus manajemen laba di Indonesia terjadi pada PT Lippo Karawaci Tbk. yang terletak di kawasan millennium village, Tanggerang, Banten. Dari pernyataan Reza Priyambada, senior Analyst CSA Research Institute yang dikutip dari Bisnis.com pada Rabu, 24 Oktober 2018 dijelaskan bahwa laporan keuangan PT Lippo Karawaci Tbk. mencerminkan terjadinya praktek suap atau manajemen laba yang dilakukan oleh petinggi Lippo Grup dalam kondisi laporan keuangan pada semester pertama 2018. Artinya, kejadian kasus dugaan penyuapan yang melibatkan petinggi Lippo Group belum terefleksikan disana. Serta proyek prestisius perseroan, yakni Meikarta. Namun peningkatan laba bersih yang drastis ini disebabkan oleh keuntungan atas dekonsolidasi PT Mahkota Sentosa Utama (MSU) atau pengembang Meikarta, anak perusahaan tidak langsung dari emiten berticker PT Lippo Karawaci Tbk. (LPKR) ini, dengan keuntungan bersih sebesar Rp. 1,3 triliun (Caesairo, 2018).

Permasalahan yang terdapat dalam perusahaan dapat dilihat dari adanya kasus dugaan praktek manjamen laba yang dilakukan oleh petinggi Lippo Grup, itu menunjukkan terdapat permasalahan dalam perusahaan. Hal ini akan mendorong manajemen untuk melakukan manipulasi atau rekayasa dalam menunjukan informasi laba, yang disebut manajemen laba. Menurut Ermawati, dkk. (2020), manajemen laba adalah keputusan manajer untuk memilih kebijakan akuntansi tertentu yang dianggap bisa mencapai tujuan yang mereka inginkan seperti meningkatkan laba atau mengurangi kerugian yang akan dilaporkan kepada para pemegang saham dan calon investor. Manajemen laba muncul sebagai dampak persoalan keagenan dimana terjadi ketidakselarasan kepentingan antar pemilik dan manajemen dalam suatu perusahaan. Pada suatu perusahaan praktek manajemen laba diduga dapat dipengaruhi oleh beberapa faktor seperti faktor kepemilikan manajerial, employee diff dan risiko litigasi.

Kepemilikan manajerial sebagai suatu mekanisme pengawasan yang bertujuan untuk menyelaraskan berbagai kepentingan dalam perusahaan. Kepemilikan manajerial merupakan besarnya kepemilikan saham yang di miliki oleh manajer. Murtini \&Mansyur (2012), menyatakan kepemilikan manajerial adalah jumlah kepemilikan saham oleh pihak manajemen dari seluruh modal saham perusahaan yang dikelola. Dalam sudut pandang teori akuntansi, manajemen laba sangat ditentukan oleh motivasi manajer perusahan. Motivasi 
yang berbeda akan menghasilkan besaran manajemen laba yang berbeda, seperti antara manajer yang berbeda yang juga sekaligus sebagai pemegang saham dan manajer yang tidak sebagai pemegang saham. Penelitian yang dilakukan Yolanda, dkk (2019), menemukan kepemilikan manajerial mempunyai pengaruh positif terhadap Earning Management. Namun, berbeda dengan penelitian Mahariana\& Ramantha (2014), menemukan kepemilikan manajerial berpengaruh negatif pada manajemen laba.

Faktor lain yang dapat mempengaruhi manajemen laba yaitu employee diff. Employee diff mreupakan faktor non finansial yang diduga dapat memepengaruhi praktek manajemen laba didalam suatu perusahaan. Menurut Nazalia \& Triyanto (2018), menyatakan bahwa employee diff merupakan kondisi dimana terdapat kesenjangan antara pertumbuhan karyawan dengan pertumbuhan pendapatan. Perusahaan berusaha untuk menutupi penurunan kinerja keuangan dengan mengurangi jumlah karyawan dengan tujuan untuk menaikkan laba perusahaan. Oleh karena itu, pengeluaran tenaga kerja harus dibebankan, sehingga beban ini akan dibuat seolah-olah kecil untuk menaikkan jumlah laba perusahaan. Penelitian yang dilakukan Kurniasih (2017), menyimpulkan bahwa employee diff tidak berpengaruh terhadap manajemen laba. Berbeda dengan penelitian yang dilakukan oleh Saputri \& Achmad (2017), menemukan bahwa emloyee diff berpengaruh secara positif dan signifikan terhadap manajemen laba.

Selain employee diff, Risiko litigasi juga mempengaruhi praktek manajemen laba. Menurut Mutiah (2018), risiko litigasi merupakan risiko yang melekat pada perusahaan yang memungkinkan terjadinya ancaman litigasi oleh pihak-pihak yang berkepentingan diperusahaan, antara lain investor, kreditor dan regulator yang lain. Risiko litigasi dapat terjadi dikarenakan kesalahan pelaporan keuangan yang sering terjadi pada perusahaan yang telah go public. Ketika perusahaan menghadapi kesulitan keuangan, investor akan cenderung untuk melakukan penggantian manajer yang tidak sanggup menangani kondisi tersebut, tekanan ini mendorong manajer untuk melakukan manipulasi laporan keuangan yang menjadi ukuran prestasi mereka. Oleh karena itu, risiko litigasi diharapkan dapat memperkecil kemungkinan terjadinya manajemen laba dengan menyajikan laporan audit yang sesuai dengan fakta, laporan hasil audit tersebut dapat berpengaruh terhadap risiko litigasi dalam memperkecil manajemen laba. Penelitian yang dilakukan Awalia (2014), menemukan risiko litigasi berpengaruh positif signifikan terhadap discretionary accruals. Namun, berbeda dengan hasil penelitian Paramita (2017), menemukan risiko litigasi berpengaruh negatif dan signifikan terhadap manajemen laba.

Berdasarkan beberapa hasil penelitian terdahulu yang tidak konsisten tersebut, maka akan dilakukan penelitian dengan judul "Pengaruh Kepemilikan Manajerial, Employee Diff, dan Risiko Litigasi Terhadap Manajemen Laba pada Perusahaan Manufaktur yang terdaftar di Bursa Efek Indonesia Tahun 2016-2018”.

Tujuan dari penelitian ini yaitu: (1) untuk mengetahui pengaruh kepemilikan manajerial terhadap manajemen laba pada perusahaan manufaktur yang terdaftar di bursa efek indonesia tahun 2016-2018. (2) untuk mengetahui pengaruh employee diff terhadap manajemen laba pada perusahaan manufaktur yang terdaftar di bursa efek indonesia tahun 2016-2018. (3) untuk mengetahui pengaruh risiko litigasi terhadap manajemen laba pada perusahaan manufaktur yang terdaftar di bursa efek indonesia tahun 2016-2018.

Hubungan antara kepemilikan manajerial dengan manajemen laba terdapat pada motivasi manajer. Menurut Purnama (2017), kepemilikan manajerial adalah persentase jumlah kepemilikan saham yang dimiliki oleh manajemen 
dari seluruh sejumlah saham perusahaan saham akan memiliki motivasi yang sebagai pemegang saham. Perbedaan yang dilakukan manajemen, termasuk kepemilikan saham oleh manajer akan dalam pengambilan keputusan terhadap perusahaan yang mereka kelola. Oleh mempengaruhi keputusan manajemen

yang beredar. Manajer sebagai pemegang berbeda dengan manajer yang bukan tersebut akan berpengaruh pada tindakan praktik manajemen laba karena menjadi salah satu faktor yang berperan metode akuntansi yang diterapkan dalam karena itu, kepemilikan manajerial lebih dalam melakukan praktik manajemen laba. Penelitian ini didukung oleh penelitiaan yang dilakukan oleh Yolanda, dkk. (2019), yang menunjukkan bahwa kepemilikan manajerial berpengaruh positif terhadap earning management. Berdasarkan uraian diatas, maka hipotesis dapat dirumuskan:

$H_{1}$ : Kepemilikan manajerial berpengaruh positif dan signifikan terhadap manajemen laba.

Beberapa faktor yang mendorong manajer untuk mengubah laba ke tingkat laba yang mereka inginkan karena kegagalan bisnis, kerugian yang sangat besar dan persaingan yang ketat (Bukit \& Nasution, 2015). Jika manajer dapat mengubah data finasial seperti penjualan, pendapatan dan laba, maka seorang manajer juga dapat mengubah data non finasial seperti kepuasan konsumen, jumlah fasilitas dan pertumbuhan karyawan. Namun, data non finansial tidak dapat dimanipulasi secara singkat. Data yang tidak kompatibel antara pertumbuhan pendapatan dan pertumbuhan karyawan yang disebut dengan employee diff, dapat memancing kecurigaan bahwa perusahaan tidak memberikan informasi keuangan yang nyata, sehingga hal ini dapat memicu manajer melakukan manajemen laba. Employee diff merupakan variabel yang digunakan untuk mengukur perbedaan antara pendapatan (data keuangan) dengan jumlah karyawan (data non keuangan). Penelitian ini didukung oleh penelitian yang dilakukan oleh Saputri \& Achmad (2017), hasil penelitian menunjukkan bahwa employee diff berpengaruh secara positif dan signifikan terhadap manajemen laba. Berdasarkan uraian diatas, maka hipotesis dapat dirumuskan:

$\mathrm{H}_{2}$ : Employee diff berpengaruh positif dan signifikan terhadap manajmen laba.

Risiko litigasi merupakan risiko yang melekat pada perusahaan yang memungkinkan terjadinya ancaman litigasi oleh pihak yang berkepentingan dengan perusahaan yang merasa dirugikan. Menurut Fitri (2015), risiko litigasi adalah proses dimana seseorang individu atau badan membawa sengketa kasus ke pengadilan. Tuntutan litigasi dapat timbul dari berbagai pihak seperti investor, kreditor, dan pihak lainnya. Oleh karena itu, adanya kesalahan akibat ketidakpatuhan terhadap standar akuntansi akan mudah dijadikan bahan tuntutan karena laporan keuangan merupakan dasar pijakan utama dalam melakukan tuntutan hukum. Selain itu, perusahaan juga bisa menerima tuntutan hukum karena hal lain seperti kelalaian akan tanggungjawab sosialnya. Litigasi juga dapat timbul karena perusahaan berusaha menutupi informasi penting perusahaan. Ada dua kemungkinan yang bisa dilakukan manajemen jika memiliki risiko litigasi yang tinggi yaitu dengan meningkatkan praktik atau bahkan mengurangi praktik manajemen laba. Penelitian ini didukung oleh penelitian yang dilakukan oleh Awalia (2014) yang menyatakan bahwa risiko litigasi berpengaruh positif dan signifikan terhadap discretionary accruals. Berdasarkan uraian diatas, maka hipotesis dapat dirumuskan:

$H_{3}$ : Risiko litigasi berpengaruh positif dan signifikan terhadap manajemen laba. 


\section{Metode}

Penelitian ini menggunakan metode penelitian kuantitatif. Populasi dalam penelitian ini adalah perusahaan yang terdaftar di Bursa Efek Indonesia pada tahun 2016-2018 sebanyak 144 perusahaan. Sampel dalam penelitian ini adalah perusahaan-perusahaan yang terdaftar secara terus-menerus di Bursa Efek Indonesia pada tahun 2016-2018 yang sudah memenuhi kriteria yang telah ditetapkan. Teknik pengambilan sampel menggunakan purposive sampling yaitu pemilihan sampel diperoleh dengan pertimbangan atau kriteria tertentu sehingga diperoleh sampel sebanyak 99 perusahaan. Dalam ini menggunakan data sekunder yang di dapat dari laporan tahunan perusahaan yang terdaftar di Bursa Efek Indonesia tahun 2016-2018 melalui Statistic Indonesia Stock Exchange (IDX) pada situs website resmi www.idx.co.id. Untuk teknik pengumpulan data yang digunakan dalam penelitian ini yaitu menggunakan Teknik pencatatan dokumen dengan mengunduh data laporan keuangan tahunan. Data yang digunakan adalah neraca dan laporan laba/rugi serta informasi yang terdapat di laporan tahunan pada perusahaan yang terdaftar di Bursa Efek Indonesia tahun 2016-2018.

Metode untuk menganalisis data dalam penelitian ini menggunakan beberapa pengujian yaitu: uji statistik deskriptif, uji asumsi klasik yang terdiri dari uji normalitas, uji multikolonearitas, uji autokolerasi, uji heteroskedastisitas, serta pengujian hipotesis yang menggunakan analisis regresi berganda. Data yang sudah terkumpul kemudian diolah dengan menggunakan program SPSS (Statistical Product and Service Solution) versi 20.0.

\section{Hasil dan Pembahasan}

Hasil dari penelitian ini yang datanya bersumber dari pencatatan dokumen laporan tahunan perusahaan yang berjumlah 297 data adalah sebagai berikut. Hasil pengujian dari uji statistik deskriptif diperoleh hasil analisis yang menunjukkan bahwa data variabel kepemilikan manajerial memiliki nilai minimum sebesar 1,41, nilai maksimum sebesar 5,00, nilai rata-rata (mean) sebesar 2,5346 dan nilai standar deviasi sebesar 0,52094.2. Variabel employee diff memiliki nilai minimum sebesar 1,06, nilai maksimum sebesar 3,61, nilai rata-rata (mean) sebesar 2,0700 dan nilai standar deviasi sebesar 0,51833. Variabel risiko litigasi memiliki nilai minimum sebesar 1,01, nilai maksimum sebesar 3,20, nilai rata-rata (mean) sebesar 1,7164 dan nilai standar deviasi sebesar 0,44086. Dan variabel manajemen laba memiliki nilai minimum sebesar 1,00 , nilai maksimum sebesar 2,65, nilai rata-rata (mean) sebesar 1,3353 dan nilai standar deviasi sebesar 0,30004.

Uji normalitas data dilakukan dengan uji Kolmogorov-Smirnov. Jika angka signifikansi Kolmorogov-Smirnov Sig > 0,05 maka menunjukkan bahwa data berdistribusi normal, sebaliknya jika angka signifikansi Kolmorogov-Smirnov Sig < 0,05 maka menunjukkan bahwa data tidak berdistribusi normal. Berdasarkan hasil pengujian diatas, diperoleh Kolmogorov-Smirnov $Z$ sebesar 1,232 dengan nilai signifikansi (Asymp. Sig. 2-tailed) 0,096. Signifikansi lebih dari 0,05 maka dapat disimpulkan data tersebut berdistribusi normal. 
Table 1. Uji Normalitas

\begin{tabular}{llr}
\hline & & Unstandardized Residual \\
\hline $\mathrm{N}$ & & 297 \\
\hline \multirow{2}{*}{ Normal Parameters } & Mean & $0 \mathrm{E}-7$ \\
\cline { 2 - 3 } Most Extreme Differences & Std. Deviation & .15875758 \\
\cline { 2 - 3 } & Absolute & .072 \\
\cline { 2 - 3 } & Positive & .072 \\
\cline { 2 - 3 } & Negative & -.053 \\
\hline Kolmogorov-Smirnov Z & & 1.232 \\
\hline Asymp. Sig. (2-tailed) & & .096 \\
\hline
\end{tabular}

Sumber: Data diolah, 2020

Untuk mendeteksi ada atau tidaknya multikolinearitas di dalam model regresi adalah mempunyai angka tolerance diatas (>) 0,1 dan mempunyai nilai VIF di bawah $(<)$ 10. Berdasarkan tabel 2 diatas dapat dilihat bahwa seluruh variabel dalam penelitian ini memiliki nilai tolerance lebih dari 0,1 dan VIF dibawah 10. Dapat disimpulkan bahwa tidak terjadi multikolinieritas

Tabel 2. Uji Multikolinearitas

\begin{tabular}{lccl}
\hline \multirow{2}{*}{ Model } & \multicolumn{2}{c}{ Collinearity Statistics } & \multirow{2}{*}{ Keterangan } \\
\cline { 2 - 3 } & Tolerance & VIF & Bebas Multikolinearitas \\
\hline Kepemilikan Manajerial & 0,342 & 2,922 & Bebas Multikolinearitas \\
\hline Employee Diff & 0,366 & 2,733 & Bebas Multikolinearitas \\
\hline Risiko Litigasi & 0,700 & 1,428 & \\
\hline
\end{tabular}

Sumber: Data diolah,2020

Uji autokorelasi adalah uji untuk menilai apakah dalam model regresi linear ada korelasi antara kesalahan pengganggu pada periode $\mathrm{t}$ dengan kesalahan pengganggu pada periode $\mathrm{t}-1$ (sebelumnya). Untuk menjelaskan ketentuan daerah terjadinya autokorelasi positif atau negatif, maupun tidak terjadi autokorelasi. Berdasarkan gambar 1 hasil uji Durbin Watson dalam penelitian ini diketahui bahwa nilai DW sebesar 0,160 yang berarti nilai DW berada diantara -2 dan $+2(-2<0,160<+2)$ maka dapat disimpulkan bahwa tidak terjadi autokorelasi dalam model regresi penelitian ini.

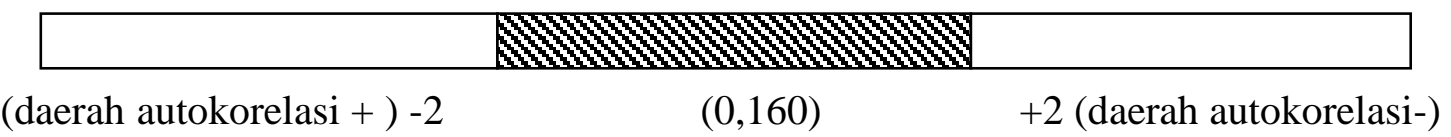

Gambar 1. Uji Autolorelasi

Uji Heteroskedastisitas merupakan asumsi dalam regresi dimana varian dari residual tidak ada yang sama untuk satu pengamatan ke pengamatan lainnya. Untuk mendeteksi ada tidaknya heteroskedastisitas dilakukan dengan melihat grafik plot antara variabel terikat (ZPRED) dengan residualnya (ZRESID), jika tidak ada membentuk suatu pola, serta titik-titik penyebaran di atas dan di bawah nilai 0 pada sumbu Y, maka tidak terhadi heteroskedastisitas. Berdasarkan hasil uji multikolonearitas pada gambar 2 terlihat bahwa titik-titik menyebar secara acak serta tersebar di atas dan juga di bawah angka 0 pada sumbu $\mathrm{Y}$ 


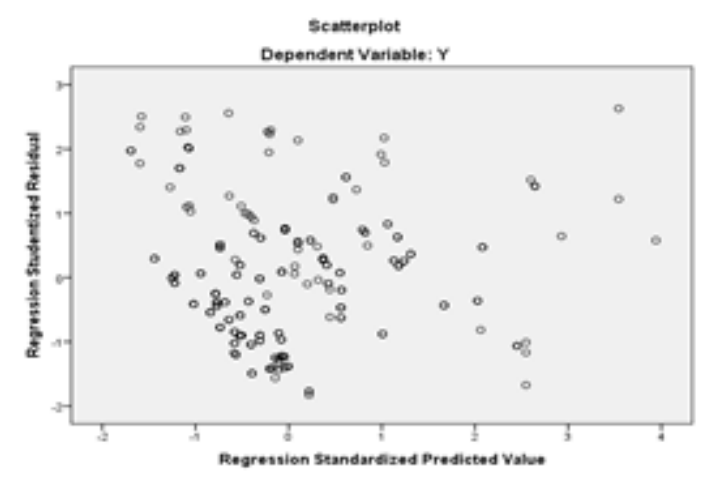

Gambar 2. Uji Heteroskedastisitas

Koefisien determinasi $\left(\mathrm{R}^{2}\right)$ digunakan untuk mengukur seberapa sumbangan pengaruh variabel bebas terhadap variabel terikat. Berdasarkan hasil penelitian diperoleh nilai $\mathrm{R}^{2}$ sebesar 0,720 menunjukkan bahwa pengaruh variabel bebas terhadap variabel terikat sebesar $72 \%$. Sedangkan sisanya dipengaruhi oleh variabel lain yang tidak ada didalam model regresi linier.

Tabel 3 Uji Koefisien Determinasi $\left(\mathrm{R}^{2}\right)$

\begin{tabular}{lrrrr}
\hline Model & R & R Square & Adjusted R Square & Std. Error of the Estimate \\
\hline 1 & $0,849^{\mathrm{a}}$ & 0,720 & 0,717 & 0,15957 \\
\hline
\end{tabular}

Sumber: Data diolah, 2020

Model analisis yang digunakan pada penelitian ini adalah analisis regresi linear berganda. Teknik ini digunakan untuk mencari ada tidaknya pengaruh dan hubugan antara variabel bebas yaitu kepemilikan manajerial, employee diff dan risiko litigasi terhadap variabel terikat manajemen laba. pengujian ini dilakukan dengan bantuan program SPSS 20 for windows. Berdasarkan tabel 4 didapat model persamaan regresi linier berganda sebagai berikut.

$$
\mathrm{Y}=0,123+0,081 \mathrm{X}_{1}+0,264 \mathrm{X}_{2 .}+0,269 \mathrm{X} 3+\varepsilon
$$

Interpretasi regresi linier berganda yang terdapat pada tabel 4, dapat dijabarkan sebagai berikut. (1) Konstanta sebesar 0,123 artinya apabila kepemilikan manajerial $\left(\mathrm{X}_{1}\right)$, employee diff $\left(\mathrm{X}_{2}\right)$ dan risiko litigasi nilainya sama dengan nol, maka nilai dari manajemen laba (Y) sebesar 0,123. (2) Nilai koefisien kepemilikan manajerial $\left(\beta_{1}\right)$ sebesar 0,081 berpengaruh positif terhadap manajemen laba (Y). Hal ini mengandung arti bahwa setiap peningkatan kepemilikan manajerial $\left(\mathrm{X}_{1}\right)$ sebesar satu satuan, maka nilai manajemen laba $(\mathrm{Y})$ akan mengalami peningkatan sebesar 0,204 dengan asumsi bahwa variabel bebas yang lainnya tetap. (3) Nilai koefisien employee diff $\left(\beta_{2}\right)$ sebesar 0,264 berpengaruh positif terhadap manajemen laba (Y). Hal ini mengandung arti bahwa setiap peningkatan employee diff $\left(\mathrm{X}_{2}\right)$ sebesar satu satuan, maka nilai manajemen laba (Y) akan mengalami peningkatan sebesar 0,387 dengan asumsi bahwa variabel bebas yang lainnya tetap. (4) Nilai koefisien risiko litigasi $\left(\beta_{3}\right)$ sebesar 0,269 berpengaruh positif terhadap manajemen laba (Y). Hal ini mengandung arti bahwa setiap peningkatan risiko litigasi $\left(\mathrm{X}_{3}\right)$ sebesar satu satuan, maka nilai manajemen laba (Y) akan mengalami peningkatan sebesar 0,392 dengan asumsi bahwa variabel bebas yang lainnya tetap. 
Tabel 4 Analisis Regresi Linier Berganda

\begin{tabular}{llccc}
\hline \multirow{2}{*}{ Model } & \multicolumn{2}{c}{ Unstandardized } & Coefficients & $\begin{array}{c}\text { Standardized } \\
\text { Coefficients }\end{array}$ \\
\cline { 3 - 5 } & & $\boldsymbol{B}$ & Std. Error & Beta \\
\hline \multirow{2}{*}{1} & (Constant) & 0,123 & 0,048 & \\
\cline { 2 - 5 } & Kepemilikan Manajerial & 0,081 & 0,030 & 0,141 \\
\cline { 2 - 5 } & Employee Diff & 0,264 & 0,030 & 0,455 \\
\cline { 2 - 5 } & Risiko Litigasi & 0,269 & 0,025 & 0,395 \\
\hline
\end{tabular}

Sumber: Data diolah, 2020

Uji t digunakan untuk menentukan analisis pengaruh kepemilikan manajerial, employee diff dan risiko litigasi terhadap manajemen laba secara parsial. Berdasarkan tabel 5 hasil dari uji t adalah sebagai berikut. (1) variabel kepemilikan manajerial memiliki nilai signifikansi uji $\mathrm{t}$ sebesar 0,008, dimana nilai tersebut lebih kecil dari 0,05 sehingga $\mathrm{H}_{1}$ diterima. Dapat disimpulkan bahwa kepemilikan manajerial berpengaruh positif dan signifikan terhadap manajemen laba. (2) variabel employee diff memiliki nilai signifikansi uji t sebesar 0,000, dimana nilai tersebut lebih kecil dari 0,05 sehingga $\mathrm{H}_{2}$ diterima. Dapat disimpulkan bahwa employee diff berpengaruh positif dan signifikan terhadap manajemen laba. (3) variabel risiko litigasi memiliki nilai signifikansi uji t sebesar 0,000, dimana nilai tersebut lebih kecil dari 0,05 sehingga $\mathrm{H}_{3}$ diterima. Dapat disimpulkan risiko litigasi berpengaruh positif dan signifikan terhadap manajemen laba

Tabel 5 Uji t

\begin{tabular}{llcc}
\hline \multicolumn{1}{c}{ Model } & $\boldsymbol{T}$ & Sig. \\
\hline \multirow{2}{*}{1} & (Constant) & 2,562 & 0,011 \\
\cline { 2 - 4 } & Kepemilikan Manajerial & 2,659 & 0,008 \\
\cline { 2 - 4 } & Employee Diff & 8,913 & 0,000 \\
\cline { 2 - 4 } & Risiko Litigasi & 10,683 & 0,000 \\
\hline
\end{tabular}

\section{Hubungan Kepemilikan Manajerial Terhadap Manajemen Laba}

Berdasarkan pengaruh kepemilikan manajerial terhadap manajemen laba pada perusahaan manufaktur yang terdaftar di Bursa Efek Indonesia. Hasil uji regresi linier berganda memperoleh nilai koefisien determinasi $\operatorname{Pyx}_{1}=0,154$ dengan sig $0,008<\alpha \quad 0,05$ maka keputusan yang diambil adalah menolak $\mathrm{H}_{0}$ yang berarti ada pengaruh antara kepemilikan manajerial terhadap manajemen laba pada perusahaan manufaktur yang terdaftar di Bursa Efek Indonesia. Besar sumbagan pengaruhya sebesar 2,37\%. Hasil penelitian yang dilakukan menunjukkan bahwa kepemilikan manajerial berpengaruh positif dan signifikan terhadap manajemen laba pada perusahaan manufaktur yang terdaftar di Bursa Efek Indonesia tahun 20162018. Dengan adanya kepemilikan saham oleh pihak manajemen maka dapat menyelaraskan kepentingan antara pihak manajemen dan pemegang saham dimana tidak terdapat keinginan untuk menguntungkan pribadi sendiri. Hal ini dapat mengurangi konflik antara pemegang saham (principal) dan pihak manajemen (agent) sehingga pihak manajemen akan lebih meningkatkan kualitas pelaporan dengan cara menyajikan laporan keuangan secara aktual demi menjaga reputasi perusahaan. Menurut perspektif teori keagenan yaitu konflik kepentingan antara pemegang saham dan pihak manajemen perusahaan dapat diminimalisir dengan adanya kepemilikan saham oleh pihak manajerial. Kepemilikan manajerial dapat menekan manajemen laba pada perusahaan. Hal ini terjadi karena manajemen laba ditentukan oleh motivasi seorang manajer dalam sebuah perusahaan. Hubungan antara 
kepemilikan manajerial dengan manajemen laba terdapat pada motivasi manajer. Semakin tinggi kepemilikan saham oleh manajerial maka semakin tinggi pula kemungkinan seorang manajer dalam melakukan praktek manajemen laba.

\section{Hubungan Employee Diff terhadap Manajemen Laba}

Berdasarkan pengaruh employee diff terhadap manajemen laba pada perusahaan manufaktur yang terdaftar di Bursa Efek Indonesia. Hasil uji regresi linier berganda memperoleh nilai koefisien determinasi $\mathrm{Pyx}_{2}=0,462$ dengan sig $0,000<\alpha 0,05$ maka keputusan yang diambil adalah menolak $\mathrm{H}_{0}$ yang berarti ada pengaruh antara kepemilikan manajerial terhadap manajemen laba pada perusahaan manufaktur yang terdaftar di Bursa Efek Indonesia. Besar sumbagan pengaruhya sebesar $21,34 \%$. Hasil penelitian yang dilakukan menunjukkan bahwa employee diff berpengaruh positif dan signifikan terhadap manajemen laba pada perusahaan manufaktur yang terdaftar di Bursa Efek Indonesia tahun 2016-2018. Dengan arah pengujian yang positif hal ini mengindikasikan bahwa dalam keadaan employee diff yang tinggi maupun rendah, tetap ada kemungkinan manajer perusahaan melakukan manipulasi laba. Dalam sebuah perusahaan karyawan merupakan hal yang sangat penting dalam keberlangsungan kegiatan operasional suatu perusahaan. Tanpa adanya karyawan didalam sebuah perusahaan, maka perusahaan tidak dapat berjalan sebagaimana mestinya. Jumlah tenaga kerja yang tinggi akan mengakibatkan tingginya biaya pengeluaran perusahaan, karena biaya tenaga kerja harus dibebankan ketika terjadi jumlah karyawan tinggi dalam suatu perusahaan. Hal ini dapat mengakibatkan menurunnya tingkat pendapatan disuatu perusahaan. Untuk mengatasi masalah tersebut diduga manajer akan berusaha untuk menutupi penurunan kinerja keuangan dengan mengurangi jumlah karyawan perusahaan, dengan tujuan untuk menaikan laba bersih perusahaan.

\section{Hubungan Risiko Litigasi terhadap Manajemen Laba}

Berdasarkan pengaruh risiko litigasi terhadap manajemen laba pada perusahaan manufaktur yang terdaftar di Bursa Efek Indonesia. Hasil uji regresi linier berganda memperoleh nilai koefisien determinasi $\mathrm{Pyx}_{3}=0,529$ dengan sig $0,000<\alpha$ 0,05 maka keputusan yang diambil adalah menolak $\mathrm{H}_{0}$ yang berarti ada pengaruh antara kepemilikan manajerial terhadap manajemen laba pada perusahaan manufaktur yang terdaftar di Bursa Efek Indonesia. Besar sumbagan pengaruhya sebesar 27,98\%. Hasil penelitian yang dilakukan menunjukkan bahwa risiko litigasi berpengaruh positif dan signifikan terhadap manajemen laba pada perusahaan manufaktur yang terdaftar di Bursa Efek Indonesia tahun 2016-2018. Risiko litigasi merupakan suatu risiko mendapatkan tuntutan hukum dari pihak eksternal baik investor, calon investor, stakeholder maupun pihak-pihak lain yang menggunakan laporan keuangan perusahaan untuk mengambil keputusan yang dikarenakan pihak-pihak tersebut merasa dirugikan. Litigasi juga dapat timbul karena perusahaan berusaha menutupi informasi penting perusahaan. Ketika perusahaan menghadapi kesulitan keuangan, investor akan cenderung untuk melakukan penggantian manajer perusahaan yang tidak sanggup menangani kondisi tersebut, tekanan ini mendorong seorang manajer untuk melakukan manipulasi laporan keuangan yang menjadi ukuran prestasi mereka. Hal ini yang membuat manajer suatu perusahaan melakukan praktek manjemen laba pada perusahaan. Semakin tinggi tingkat risiko litigasi perusahaan maka manajemen akan berusaha menutupinya dengan cara memanipulasi laporan keuangan agar terlihat baik bagi para pihak yang berkepentingan seperti 
investor maupun calon investor agar mereka tetap percaya dan tertarik berinvestasi didalam perusahaan.

\section{Simpulan dan Saran}

Berdasarkan pada analisis data yang telah dilakukan, maka dapat ditarik kesimpulan sebagai berikut. (1) Kepemilikan manajerial berpengaruh positif dan signifikan terhadap manajemen laba. Hasil pengujian memberikan implikasi bahwa semakin meningkat kepemilikan manajerial maka manajemen laba juga akan semakin meningkat. (2) Employee diff berpengaruh positif dan signifikan terhadap manajemen laba. Hasil pengujian memberikan implikasi bahwa semakin meningkat employee diff maka manajemen laba juga akan semakin meningkat. (3) Risiko litigasi berpengaruh positif dan signifikan terhadap manajemen laba. Hasil pengujian memberikan implikasi bahwa semakin meningkat risiko litigasi maka manajemen laba juga akan semakin meningkat.

Berdasarkan hasil pembahasan dan simpulan yang telah dikemukakan, maka saran yang dapat dianjurkan sebagai berikut. (1) Bagi peneliti selanjutnya, dapat menambahkan menambah variabel lain selain variabel yang digunakan dalam penelitian ini yang mungkin dapat mempengaruhi manajemen laba seperti free cash flow. Selain itu bagi peneliti selanjutnya disarankan untuk menggunakan skala pengukuran yang berbeda, dengan sektor perusahaan yang berbeda juga. (2) Bagi investor, diharapkan investor untuk lebih berhati-hati dalam melalukan investasi di dalam suatu perusahaan. Dengan melihat tingkat kepemilikan manajerial, employee diff dan risiko litigasi yang dimiliki suatu perusahaan dapat mengindari terjadinya manajemen laba yang dilakukan dalam perusahaan. Investor diharapkan agar memilih perusahaan yang memiliki tingkat kepemilikan manajerial, employee diff dan risiko litigasi yang rendah untuk berinvestasi agar menghindari manajemen laba di suatu perusahaan. (3) Bagi perusahaan, harus lebih memperhatikan kegiatan monitoring yang dilakukan oleh pemilik perusahan dan investor selaku pemegang saham perusahaan. Kegiatan monitoring menjadi solusi bagi perusahaan agar tidak terjadinya manajemen laba di perusahaan. Investor yang aktif dalam melakukan monitoring, akan membuat perusahaan lebih banyak mengungkap praktek manajemen laba disuatu perusahaan.

\section{Daftar Pustaka}

Awalia, A. (2014). Pengaruh risiko litigasi terhadap kualitas pelaporan keuangan dengan keahlian hukum komite audit sebagai variabel pemoderasi. UNIVERSITAS DIPONEGORO.

Bukit, R. B., \& Nasution, F. N. (2015). Employee Diff, Free Cash Flow, Corporate Governance and Earnings Management. Procedia - Social and Behavioral Sciences, 211(September), 585-594. https://doi.org/10.1016/j.sbspro.2015.11.077

Caesairo, Emanuel, B. 2018. Laba Lippo Karawaci (LPKR) Melonjak 135\%, Ini Tanggapan Analis. Tersedia pada https://market.bisnis.com/read/20181025/191/853024/laba-lippokarawaci-lpkr-melonjak-135-ini-tanggapan-analis. Bisnis.com. Diakses pada 12 Februari 2020.

Ermawati, E., Maslichah, \& Anwar, S. A. (2020). Pengaruh Kompensasi, Kepemilikan Manajerial, Diversifikasi Perusahaan Dan Ukuran Kap Terhadap Manajemen Laba Pada Perusahaan Manufaktur Yang Terdaftar Di Bursa Efek Indonesia Tahun 2016-2018. Fakultas Ekonomi Dan Bisnis Universitas Islam Malang, E-JRA Vol.(06), 1-16. 
Fitri, R. Y. (2015). Pengaruh Risiko Litigasi Terhadap Hubungan Kesulitan Keuangan Dan Konflik Kepentingan Dengan Konservatisme Akuntansi. In Jurnal Skripsi Universitas Negeri Padang.

Kurniasih, S. (2017). Pengaruh Employee Diff, Peran Auditor, dan Karakteristik Budaya Terhadap Manipulasi Laba.

Mahariana, I., \& Ramantha, I. (2014). Pengaruh Kepemilikan Manajerial Dan Kepemilikan Institusional Terhadap Manajemen Laba Pada Perusahaan Manufaktur Di Bei. E-Jurnal Akuntansi Universitas Udayana, 7(2), 519-528.

Murtini, U., \& Mansyur, R. (2012). Pengaruh Corporate Governance terhadap Manajemen Laba Perusahaan di Indonesia. Jurnal Riset Akuntansi Dan Keuangan, 8(1), 69-78. ejournalfb.ukdw.ac.id

Mutiah. (2018). Pengaruh Asimetri Informasi, Analyst Coverage Dan Risiko Litigasi Terhadap Konservatisme Akuntansi (Studi Pada Perusahaan Manufaktur yang Masuk dalam Indeks Saham Syariah Indonesia (ISSI) yang Terdaftar di Bursa Efek Indonesia Periode 2014-2017).

Nazalia, N., \& Triyanto, D. N. (2018). Pengaruh Free Cash Flow, Financial Distress, dan Employee Diff Terhadap Manajemen Laba. Jurnal Akuntansi, Audit, Dan Sistem Informasi Akuntansi, 2(3), 93-103.

Ni Nyoman Erni Yanuar Paramita, Edy Sujana, N. T. H. (2017). Pengaruh Financial Distress , Risiko Litigasi Dan Pengungkapan Corporate Social Responsibility Terhadap Manajemen Laba ( Studi Empiris pada Perusahaan Manufaktur yang Terdaftar di Bursa Efek Indonesia Periode 2014-2016 ) e-Journal Akuntansi S1 Universitas. E-Journal Akuntansi S1, 8(2).

Priswita, F., \& Taqwa, S. (2019). Pengaruh corporate governance terhadap kecurangan laporan keuangan. Jurnal Eksplorasi Akuntansi, 1(4), 1705-1722. http://jea.ppj.unp.ac.id/index.php/jea/issue/view/14\%0D

Purnama, D. (2017). Pengaruh Profitabilitas, Leverage, Ukuran Perusahaan, Kepemilikan Institusional Dan Kepemilikan Manajerial Terhadap Manajemen Laba. Jurnal Riset Keuangan Dan Akuntansi, 3(1), 1-14. https://doi.org/10.25134/jrka.v3i1.67

Wanda Saputri, G. O., \& Achmad, T. (2017). Pengaruh Faktor Finansial Dan Non Finansial Terhadap Manajemen Laba (Studi Empiris pada Perusahaan Manufaktur yang Terdaftar di Bursa Efek Indonesia Periode 2013-2015). JOURNAL OF ACCOUNTING, 6(3), 118728.

Yolanda, M., Hapsari, K. W., Akbar, S. N., \& Herawaty, V. (2019). Pengaruh kepemilikan manajerial dan kualitas audit terhadap earning management dengan financial distress sebagai variabel intervening (studi empiris pada perusahaan manufaktur yang terdaftar di bei 2015-2017). Akuntansi, 1-8. 